\title{
Para os editores dos Anais Brasileiros de Dermatologia
}

Foi com surpresa que encontrei em nosso "Jornal da SBD (jan/fev 2011)" a informação sobre o aceite de artigos para os Anais Brasileiros de Dermatologia, somente em inglês - a partir de 2012. Não foi agradável ver que a nossa língua não possa mais ser utilizada para os artigos científicos dos Anais Brasileiros de Dermatologia!

$\mathrm{Na}$ verdade, eu (e, creio, muitos outros) esperava que isto viesse a acontecer. Aliás, já vinha acontecendo. Já tínhamos uma versão inglesa, "on line", dos artigos.

Acho que os Anais Brasileiros de Dermatologia evoluíram muito ao longo dos últimos anos, atingindo ótimo padrão. Ao longo da sua história, muitos trabalharam (e trabalham) para que a nossa revista atingisse o padrão internacional atual.

Como sabemos, a revista foi indexada.

A revista foi indexada, porém, o fator de impacto da revista é baixo.

Aumentar o fator de impacto (e mantê-lo) é essencial para as revistas científicas. Em geral, quanto maior o fator de impacto, mais artigos serão recebidos, maior será a possibilidade de melhorar a qualidade da revista, mais citações dos artigos serão feitos, maior será o impacto científico, mais conhecidos e respeita- dos serão os autores, maiores serão os créditos dos serviços que tiverem pós-graduação, maiores serão as possibilidades de vencer editais de financiamento de pesquisa. Um círculo virtuoso que, certamente, levará a pesquisas de maior qualidade e impacto.

$\mathrm{Na}$ situação atual, com os artigos escritos em português, a chance de o fator de impacto aumentar é muito reduzida. Os bons artigos dos pesquisadores nacionais não são escritos em português. São escritos em inglês e publicados em revistas internacionais.

Pior que o fator de impacto é que a nossa língua não é lida pela maioria dos pesquisadores da comunidade científica internacional. Raramente, um artigo da nossa revista é citado.

Para mim, o melhor exemplo é a publicação, em português, do Dr. Osmar Matos, sobre o tratamento do Prurigo Nodular com a talidomida. Alguém, alguma vez, já viu citação deste artigo?

Infelizmente, esta é a tendência atual. Ou publicamos em inglês ou continuaremos no esquecimento científico.

Dra. Izelda e editores dos Anais Brasileiros de Dermatologia estão de parabéns pela atitude corajosa que tomaram,

Manaus, 11 de abril de 2011.

Serviço de Dermatologia, Fundação de Medicina Tropical do Amazonas 